\title{
EL MISTERIO DEL DICCIONARIO MAYA DE SOLANA
}

\author{
Por J. Eric S. Thompson.
}

Alonso de Solana, o de la Solana, uno de los primeros fanciscanos en Yucatán, fue el autor de varios trabajos sobre temas mayas. Según fray Bernardino de Lizana, él tuvo mucho interés por la cultura maya prehispánica, y escribió extensamente al respecto. Murió en 1600 dejando por lo menos tres manuscritos, ahora perdidos, sobre la cultura maya y un Diccionario Maya (Carrillo y Ancona, 1870, según Brinton, 1897, pág. 184).

López de Cogolludo (1867-68, 2:121 y 233) unas veces nos dice que el vocabulario era pequeño y otras que era copioso. Se perdió y por mucho tiempo fue catalogado así.

Tozzer (1921, pág. 169) dio su título, tamaño y número de folios, indicando que se encontraba "probablemente en la Biblioteca de la Sociedad Hispánica de América en New York". Una nota añadía que no le fue posible verificar el dato. Más tarde se negó que la obra estuviera allí, y, en realidad, no fue llevado a esa Biblioteca hasta febrero de 1956, procedente del patrimonio del fallecido Archer Huntington, según me informó Miss Penney ,Directora de la Biblioteca.

Desconociendo este último dato, inquirí en la Biblioteca de la Sociedad Hispánica de América, a mi paso por New York a principios de 1962, si algo se sabía del Vocabulario, y en pocos minutos el esquivo volumen estuvo en mis manos. Es un vocabulario Español-Maya, impreso en cuarto, y de 115 folios, pero la última página tiene sólo algunas palabras españolas, habiéndose dejado en blanco el espacio de la derecha para los equivalentes mayas. El promedio de cada página es de cuarenta registros, pero aquellas que llevan letras mayúsculas para marcar el principio de las palabras con una nueva letra inicial, llevan solamente alrededor de 36, así es que el total de registros en todo el libro es un poco mayor de 9,000 
palabras. La escritura es bellamente clara; yo soy completamente ignorante al respecto, pero me parece difícil de creer que el manuscrito sea del siglo xvi. Una palabra ocasional fue añadida por una mano y con tinta diferentes en el área en blanco a la derecha de la columna principal de los registros.

La página que lleva el título, aparentemente de fecha reciente, dice: Vocabulario muy copioso en lengua española y maya de Yucatán compuesto por Fr. Alonso de la Solana de la orden de N. P. S. Francisco. Mérida, 1580.

Hay dos o tres detalles curiosos sobre esta página del título. Las palabras "de la" están comprimidas entre Alonso y Solana, como si hubieran sustituido en el último momento a "de". Ocurren las dos formas del nombre (Sopuerta, su superior, usa de la Solana). No es usual escribir "N. P. S." antes de Francisco; el conjunto es contracción de nuestro sefárico padre San Francisco, y debe escribirse "N. S. P. S.". "Lengua" debía de estar en plural. Es improbable que la página del título en un manuscrito lleve el nombre del lugar en que se escribió o la fecha de su terminación. Como está nombrado el lugar, es más probable que quiera decir que la obra fue redactada en el convento de frailes de Mérida. Sin embargo, en realidad, fray Alonso no residía en Mérida en 1580; y en ese tiempo 'era guardián de Conkal (Sopuerta, 1938, pág. 49). Finalmente, "vocabulario muy capioso" son palabras muy inusitadas en la página del título de un manuscrito bajo cualesquiera condiciones; en este caso son doblemente extrañas ya que el vocabulario no es muy copioso.

Por las razones asentadas, se supone que la presente página del título no es una copia de una más antigua dañada, sino una invención de su escriba del siglo xx (?). Mi breve examen del vocabulario no reveló evidencia de que haya sido escrito por Solana o por cualquier otro del ramo.

No hay, o hay muy pocas, ilustraciones gramaticales, y son muy escasas las palabras que no se encuentran en otros vocabularios. Mi ligero examen me dejó la impresión de que hay alguna relación entre el vocabulario de la Sociedad Hispánica y las partes Español-Maya de los diccionarios de San Francisco y Motul, tal vez incluso hasta con el de Ticul, como si el autor de uno de ellos hubiera tenido acceso a los otros, o todos derivaran de un antecesor perdido. Algunos errores, que se explican mejor tratándose de un copista, y las palabras 
españolas de la última página sin su equivalencia maya, mas bien nos sugieren que el Vocabulario de la Sociedad Hispánica no es el padre. Si mi impresión es correcta, el Vocabulario de la Sociedad Hispánica difícilmente puede ser la obra de de la Solana, porque las secciones Español-Maya de los vocabularios de Motul y San Francisco son del siglo xviI, y las probables fechas más recientes de fines de dicho siglo (Roys, 1952, pág. 425) como las del Ticul. Estos, sin embargo, son problemas que yo dejo a los expertos y a los que tienen acceso al material comparativo.

Parece que el libro fue comprado en Alemania por 12,000 marcos, aparentemente poco después de la primera guerra mundial cuando el marco había bajado de valor pero que no había dejado de valer. Probablemente Tozzer debe haber sido informado del libro, sea por Huntington o por algún otro que haya tenido acceso a él, porque de otro modo no hubiera conocido el número de sus folios o su ubicación. El porqué Huntington se volvió después tan misterioso respecto a su adquisición, no es muy claro, a menos que, tal vez, descubriera que no era de Solana. El misterio del Vocabulario de Solana no termina aquí.

Poco después de la muerte de William Gates, entusiasta estudioso de las lenguas mayas y no menos entusiasta coleccionista de material original relativo a su tema escogido, su hermana, Mrs. McComas, me envió una copia de la última carta escrita por él. Está fechada el 16 de marzo de 1940, poco más de un mes antes de su muerte, y comenzaba con estas palabras (el nombre del destinatario estaba suprimido):

"Estoy enviando en este momento a la imprenta la siguiente lista de volúmenes que será más que una sorpresa para usted... Primero, asombrosamente el Diccionario Maya de Solano (sic en la copia) del siglo xvi, después de haber estado oculto por cerca de treinta años, ha aparecido entre mis papeles, listo para que yo me entienda con él. Enteramente o casi igual al de Motul. Se suponía que había sido vendido a Archer Huntington durante la guerra alemana a un precio muy alto; y él, Huntington, no permitió a nadie ni siquiera echarle un vistazo. Pero el volumen que ahora tengo en las manos parece ser el original, mientras que el suyo aparentemente ha de ser sólo una co- 
pia casi contemporánea. Por supuesto, yo entrego ahora esto a la imprenta inmediatamente. No notado por mí durante treinta años." *

La carta está llena de planes exuberantes para el futuro, como eran la mayor parte de las cartas de Gates, pero no señalaba ninguna debilidad de su intelecto. ¿Pudo un acucioso investigador que conocía su materia excepcionalmente bien, haber tenido tan valiosa obra en su poder por treinta años sin saberlo? Aún más, Gates nunca vio la adquisición de Huntington, y entonces, ¿cómo pudo decir que lo que es ahora el Vocabulario de la Sociedad Hispánica fuera una copia de su recién encontrado tesoro? El Vocabulario de la Sociedad Hispánica no es extenso pero sí deficiente en ejemplos de construcción gramatical. Aún con la excitación del descubrimiento, Gates difícilmente pudo haber considerado otra edición de él como "enteramente o casi igual al de Motul", ya que con este término los investigadores se refieren a la parte MayaEspañol y no a la parte muy inferior y más reciente EspañolMaya.

Varios de los manuscritos más raros de Gates fueron comprados por su amigo Garrett, quien los donó a Princeton; el resto de la colección fue comprada por la Brigham Young University de Provo, Utah. En ninguna de estas colecciones se encuentra ningún Vocabulario de Solana (los vocabularios Cakchiquel de Solano eran ampliamente conocidos y catalogados por Gates). ¿Estaba entonces Gates sufriendo alguna desintegración mental cuando escribió esa carta? - no hay ninguna evidencia de ello en el resto de la carta- o, lo que me parece muy difícil de creer, ¿existe en alguna parte un Vocabulario de Solana del siglo xvi casi tan bueno como el Motul, y que tan misteriosamente como apareció en los archivos de Gates así desapareció? Muy aparte de las dificultades que plantea la carta de Gates, ¿quién fue el autor o compilador del Vocabulario de la Sociedad Hispánica si, como más bien sospecho, éste fue compuesto con considerable ayuda procedente de otra fuente, mucho tiempo después del último suspiro de Fray Solana?

* En su correspondencia particular Gates acostumbraba escribir con cinta roja las palabras que quería enfatizar, y las subrayada cuando escribía a mano. 


\section{BIBLIOGRAFIA}

Brinton, D. C.: The Missing Authorities on Mayan Antiquities. American Anthropologist, o. s. 10:183-91. Washington. 1897.

Carrillo y Ancona, C.: Historia de la Literatura Maya. Revista de Mérida, p. 31. Mérida. 1870.

López DE Cogolludo, D.: Historia de Yucatán. Mérida (3 edición). 1867-68.

Roys, R. L.: The Franciscan Contribution to Maya Linguistic Research in Yucatan. The Americas, Vol. 8:417-429. Washington. 1952.

Sopuerta, H. DE: Carta con una memoria de los frailes franciscanos que sirven en la provincia de Yucatán. Año de 1580. Documentos para la Historia de Yucatán, No. 2:48-50. Mérida. 1938.

Tozzer, A. M.: A Maya Grammar with Bibliography and Appraisement of the Works Noted. Peabody Museum, Papers Vol. 9. Harvard University. Cambridge. 1921. 